\title{
農村におけるライフスタイルの分析と ヘルスプロモーション技法の開発に関する研究
}

\author{
主任研究者 山 根 洋 右 \\ （島根医科大学環境保健医学教授）
}

\begin{abstract}
ライフスタイル関連疾患の増加ならびに健康に関するライフスタイルの影響の増大に対応して多 様化する農山村のライフスタイルの分析と農山村コミュニティに括ける健康増進の方略, 技法を開 発する目的で研究を行った。調査は北海道から本州, 四国, 九州を緃断し, 各研究機関が長年にわ たり健康管理を行っているモデル市町村を対象に, 第 2 年度は共通のライフスタイル調査表を用い て調査を行った。
\end{abstract}

\section{分担研究者及び研究機関}

1. 杉村 璇 (北海道: 旭川厚生総合病院院長)

2. 林 雅人（秋田県：平鹿総合病院院長）

3. 野尻雅美 (千葉県: 千葉大学看護学部教授)

4. 松島松変（長野県：佐久総合病院院長）

5. 関口善孝（広島県：廣島総合病院副院長）

6. 山根洋右（島根県：島根医科大学教授）

7. 宮原伸二（高知県：西土佐村保健センタ一所長）

8. 小山和作 (熊本県: 日赤能本健康管理センター 所長)

\section{A. 研 究 目 的}

近年, 経済発展, 情報社会化などにより都市, 農村, 山村, 漁村の地域特性が複雑化する一方、都市化傾向, 均質化傾向を示し, 健康習慣, 生活習慣, ライフスタ イルも従来と著しく変化し, 多様化の様相を深めてい る。また，保健・医療・福祉の領域に颃いても，慢性 疾患特に「ライフスタイル関連疾患」の比重が増加し, 個人・家庭レベルでのセルフヶアを核とする自己健康 管理能力や生活の質 (Quality of Life) の向上のため の方策が重要となり，コミュニティ（市町村）レベル での住民主体のヘルス・プロモーションの推進が緊要 な課題となっている。

本研究では, 変貌著しい農村社会のライフスタイル の解析を北海道, 本州, 四国, 九州と日本を縦断する 形で, 調査対象モデルコミュニティを設定し, 地域特 性（コミュニティ・プロフィール）を明らかにし，コ ミュニティに拈けるイフスタイルの現状を把握, 分
析することを目的とした。さらに，このライフスタイ ルに対応し学童から高齢者までのライフステージ毎の 健康増進技法の検討, ライフスタイル改善を志向する コミュニティのヘルス・プロモーション対策を樹立す ることを目的とした。

第 1 年度は, 産業, 経済, 保健, 医療, 福祉などの 特徵を共通項目で多角的に把握するため, コミュニ ティ・プロフィール調査表を共同作成し，これに沿っ て対象とした農山村のライフスタイルに影響すると考 えられる地域特性を把握, 分析した。さらに, 国内外 の研究報告を踏まえ QOL も加味した共通のライフス タイル調査表を作成した。

今年度は, この共通のライフスタイル調査表により 実際に調査を行い，ライフスタイルという概念の検討 を行い, 調查表の問題点を検討し修正を行った。また, 対象農山村のライフスタイルの現状と特徵的傾向を把 握し, さらに, その特徵を検討しライフスタイル調査 研究の課題を明らかにした。

\section{B. 研 究 方 法}

対象市町村は, 日本を縦断する形で, 北海道, 本州, 四国, 九州の各地域から, 日常的に共同研究班が健康 管理活動を支援している人口 5,000 ～ 15,000 人の町村 を選定した。地域特性としては，農山村を中心に，漁 村, 都市近郊農村を対象に調査を行った。調査対象地 区は次の通りである。北海道鷹栖町 (都市近郊農村), 佐呂間町 (農漁村), 秋田県増田町 (農村), 静岡県西 伊豆町 (農漁村), 賀茂村 (農漁村), 長野県臼田町 (農 村), 広島県廿日市市原 (都市近郊農村), 島根県佐田 
町 (農村), 湖陵町 (都市近郊農村), 石見町 (農村), 出雲市 (市部), 高知県西土佐村 (農村), 熊本県豊野 村 (農村)。

ライフスタイル調査は，第 1 年度に研究班で共同作 成した調査表を用いた。このライフスタイル調查表は, 成人対象のものでは，主体特性（社会経済的特性，健 康行動特性), 生活満足度 (LSI, 全般, 生活分野別, ソーシャルサポート), 健康状態, ライフスタイル, 高 齢者の機能 ADL, 健康支援環境への関心(ヘルスサー ビス利用, 環境保全への行動) の枠組みで構成されて いる。

学童用のものでは, 主体特性(健康行動特性), 生活 満足度(学校生活, 家庭生活), 健康状態, ライフスタ イルの枠組みで構成され，ライフスタイルに加穴て生 活の質 (QOL) を加味し特徵を持たせた。共同研究者 によっては，さらに独自の調査項目を付加した。

具体的調查方法は, 成人では, 地域自治会, 事業所 などへ, 学童では, 教育委員会, 学校保健会などへ事 前の主旨説明を行い, 調査結果は, プライバシー保護 上, 封書で回収し, 個人, 学校, 地域別に集計分析し て報告し，個人及び集団の今後のへルスプロモーショ ンへの活用を図った。

研究班班員の集計結果は, 班長にフロッピーで送ら れ, 各地域の集計結果はコピーされて全班員の手元に 返送され, 各研究員が全国各地の結果と比較し, 地域 の健康教育活動等に活用できるよう配慮した。な拉, 全国の集約とへルスプロモーション技法の開発の課題 は, 第 3 年度に行われる予定である。

\section{C. 結 果}

杉村ら（北海道）は，20年来, 継続して健康な町づ くりに取り組んできた鷹栖町々佐呂間町を対象に，食 生活及び食習慣, 健康習慣, 自覚的健康状態, 生活の 満足度などの年齢階層による変化をとら光た。食習慣 の中で, 摄取食品の種類は年龄階層により差があり, 摄取頻度も年齢階層により波動があることが示され た。また喏好に関する男女間の差異は，30歳までに次 第に家族の中で平均化される傾向にあり，健康と食生 活スタイルの改善は30歳以前に取り組むことが効果的 であると指摘した。食習慣について世代別にみると， 女子中学生と 30 歳代女性は良い食習慣を維持している が, 30歳男性が問題が多く, 加齢により性差は減少し 50歳代で平均化する傾向を指摘した。

健康習慣では，男女とも孤独感が30歳代に問題が多 いが50歳代までに改善され平均化していく傾向にあっ た。心理的安定度をみると男女とも孤独感が 30 歳代よ
りも50歳代で強まり心理的安定度が顕著に低下する。 健康状態は 30 歳代が自覚的に良好と答えているが，健 康なライフスタイルを実践しているのは 30 歳代よりも 50 歳代, 特に女性に高かった。現在の生活の満足度は, 男女ともに同じ傾向を示し，50歳代が満足度は低い。 特に農業者について生活の満足度をみると女性では50 歳代, 男性では60歳代で低かった。

活動能力指標, すなわち手段的自立, 知的能動性, 社会的役割をみると手段的自立が年齢とともに低下傾 向にあり, 女性の方が人生へのネガティブ意識が強く 女性の心理的不安定さ, 健康への自信の低下と関連し, 老いへの受容を拒否している様にも見えることを指摘 した。

林ら（秋田県）は，10年来，健康管理を続けている 増田町で, 自覚的健康度, 健康行動特性, 生活満足度, ライフスタイル，食習慣とともに，既往歴，健診成績 とライフスタイルとの関連を調査した。自覚的健康度 の良い人の比率は高齢になる激減し, その理由として 心理的要因の他に有病率の上昇が上げられる。高秢に なるほど良好な健康行動を実行して扣り，それを補う 生活行動がとられていた。同様に最近，治療歷をもつ 人は良好な健康行動を実行している比率が高かった。 健康診断, 人間ドック受診者も健康行動特性の良好な 人が多い。

高血圧症とその既往のある人では，男女とも健康行 動特性が良好で, この傾向は特に女性に著しい。一方, 多血症の男性ではアルコール, 契煙が, 貧血症の女性 では食生活の健康行動特性が悪かった。今回の調査で は, 肥満度, 血清総コレステロール值と健康行動特性 とは相関が見られなかった。食習慣では，高齢になる につれ食事，领酒などの注意を良く守って打り，問題 となる習慣は40，50歳代の男性に多かった。健康習慣， ソーシャルサポートとライフスタイルの関連を見る と，全般的に女性が男性よりも優れていた。これは良 いライフスタイルを持続している期間とも関係してい ると考光られる。

野尻ら（千葉県）は，30年来，健康管理を行ってい る西伊豆町と賀茂町を対象に健康診断とライフスタイ ル調査を行った。自覚的に健康であると認識している 人は20 30\%で，高年層は中年層と同様に元気で，健 康行動を実施している人が高年層に多かった。生活習 慣では，「間食」と「睡眠時間」を除き，男性よりも女 性，中年層よりも高年層の方か良い生活習慣を行って いる人が多く，男性では「間食」「休養」，女性では「栄 養」「塩分」「野菜」「酒」「タバコ」「肥満」が良く守ら れていた。ソーシャルサポートについては，社会から 
自分が支号れていると感じている人は，女性に多く， 社会に貢献していると感じている人は，男性にやや多 かった。

生活の満足度では, 高年層の女性が高く, 中年層で はやや低かった。小・中学生のライフスタイルでは, 自覚的健康度は, 小学生よりも中学生の方がやや低 かった。健康行動特性では, 小学生では「やや良好」, 中学生では「気持ちだけ」が最も多かった。健康習慣 は, 朝食, 睡眠で達成度が高く, 毎朝の排便, 毎食後 の歯磨きなど基本的生活習慣が低かった。食生活習慣 では, 朝食を家族全員で食べる者は, 夕食に比べて少 なかった。塩辛いるのの摂取はあまり気をつけていな いが青身の魚を食べる者は漁村のためか比較的多かっ た。

松島ら（長野県）は，50年来，健康管理を支援して いる臼田町を対象に集団健康スクリーニング後の健康 教育の介入方法（集団指導方法と個人指導方法）を評 価し, ライフスタイル変化と指導との効果から, 今後 のヘルスプロモーション技法の開発を目的として調査 を行った。生活改善の評価項目として, 肥満, 労働,

睡眠, 受診行動などライフスタイルに関連した17項目 を設定し, 集団健康スクリーニング後の健康教育によ る生活習慣改善率を比較した結果, 改善しにくいライ フスタイル項目として, 減量, 禁煙, 運動などが挙げ られ, 改善率は $30 \%$ 以下であった。これらの項目と比 較し, 食事, 労働, 胃健診受診などは $40 \%$ 以上の改善 がみられた。

集団指導の方法では，コミュニティレベルで周知徹 底している課題の改善率が良好な結果を示し, 個人指 導の方法では，個人指導の後にフォローして行った小 集団健康学習が課題の改善率に効果的成果を扣さめ た。今後, ライフスタイルの改善には，人を集めるた めの「ユニークなアイディア」の企画と, 企画段階か らの住民参加, 参加者へのライフスタイル改善課題へ の具体的な行動技術支援・協力と開発,「待ち」の指導 から「出向く」指導, 人生の楽しさを感じるスタッフ と住民の相互生涯学習の視点などを重視すべさことを 指摘した。

関口ら (広島県) は, 廿日市市原地区を対象に調査 を行った。自覚的健康度は, 加齢とともに低下寸るが, 健康行動特性は高年層の方が実践度が高い。健康習慣 をみると青年層, 中年層の男性は, 労働時間が長く, 充分な睡眠や休養をとる率が低く, 過度领酒者や猰煙 者が半数にみられ, 女性は労働時間, 休養は適正であ るが睡眠時間が少ない傾向を示した。これに比し高年 層は, ライフスタイル上の問題点は比較的少ない。心
理的社会的サポートの状況は, 年齢とともに, そして 女性よりも男性に弱い傾向を示した。青年層では，健 康状態は良好だが，健康習慣の行動化は消極的で行動 変容への働きかけが必要であり, 中年層は健診受診率 も低く, 男性の精神的過労, 女性の貧血傾向などへの ライフスタイル改善が課題であり, 高年層では地域の 人間関係を基盤とするンーシャルサポートが重要と考 兄られた。

山根ら (島根県) は, 19年来, 健康増進活動を行っ ている出雲市, 湖陵町, 石見町, 益田市を対象に, 自 覚的健康度, 生活満足度, ライフスタイル, 食品摄取 頻度, 既往歷を調査した。対象者は自覚的健康度を, 身体的健康のみならず, 精神的, 社会的健康とも統合 してとらえて扣り, 小児では発達課題の達成と自覚的 健康度・身体的健康度との間に強い関連を見いだした。 幼稚園児のライフスタイルは, 環境要因と成人のライ フスタイルをよく反映して扔り, 幼稚園児の調査に よって学校保健のみならず, 母子保健, 成人保健の一 ルスプロモーション課題を明確にすることができるこ とを指摘した。小児と成人では, 生活満足度に自覚的 健康度は寄与していた。満足度の低い中学生群に, 契 煙・飲酒の割合が高く, 中学生の飲酒・契煙行動は, 成人と同様にストレス回避行動であることが示唆され た。

成人に怙けるソーシャルサポートは, 自覚的健康度 よりも人生満足度との間に強い相関が認められ, 特に 若・中年層のソーシャルサポートは, 満足度に寄与し ていることが示唆された。女性の若年層と中年層は, 職場や家庭に招いて, 役割行動の大きな変動に曝され, 生きがい，働きがいの危機的状態にあることが示唆さ れた。同時に，コミュニティ特性と世代特性が，ライ フスタイルを通じて健康や満足感に大さく影響を及ぼ していることが明らかにされた。今後、コミュニティ 及び世代の特性別に, 住民の行動变容と健康学習内容, 健康的環境をつくることが重要と考兄られた。これら の集約として, 主体的要因, 環境要因, ライフスタイ ル，健康及び満足感の諸要因間の関係について因果関 係モデル図を作成した。

宮原ら（高知県）は，10年来，住民主体の全村健康 増進活動を行っている西土佐村を対象に調査を行っ た。村民の半数以上は, 健康行動, 健康習慣, 食行動 も良好に保たれているが，反面，半数近い住民には， ライフスタイルの乱れが見られた。健康習慣では, 男 性の中年層に睡眠, 運動, 休養, 節酒が, 女性では睡 眠, 労働, 運動, 栄養バランスが低かった。全体的に は健康意識の高いグループは健康行動, 食行動に打い 
ても総じて良好な結果となっているが，ソーシャルサ ポート，友人関係などに打いては問題を残して抢り， 農村特有の地域連帯の崩壊が推察された。精神的健康 に関する活動が，今後，農村に打いても重要になるも のと推察される。子どもの自覚的健康度は, 中学生で 男性 $36.5 \%$ ，女性 $16.9 \%$ が「良い」と答光ているに過 ぎず，心理精神的なストレスを伺わせる。子どもの健 康行動や健康習慣では，特に食行動に関しては大きな 食生活ライフスタイルの乱れがみられ, 食事も不規則, 塩分と糖分，スナック菓子の過㮃摂取，少ない乳製品 や野菜摂取など，小児成人病予備群の状況にある。子 ぞもの頃から健康学習を積極的に取り入れ，正しいラ イフスタイルと健康習慣を身につけることが望まれ る。

小山ら（熊本県）は，純農村の豊野村を対象として 全住民の調查を行った。健康行動特性は，若年層では 女性, 壮年層では男性が実践度が低く，農業よりも勤 務者の実践度が低かった。高年層では, 独居老人や病 気治療中の者の実践度が高く, 健康行動の実践度と自 覚的健康度とは一致しなかった。健康習慣では，ライ フスタイルの改善を要する者が 7 割存在し，職業別で は主婦が最も良好で，現業職，専門職，サービス業， 管理職いずれも不良であった。生活の満足度は，6 割 が経済状態, 余㗇活動に不満を感じ, 家庭, 近隣関係 には高い満足度を示した。職業別では管理職, 自営業, 農業者が満足度を高く, 無職, 非農家, 若年層, 独居 老人が低く，ライフスタイル良好者が満足度が高かっ た。人生満足度は管理職, 事務職, 専業農家, 若年層 に高い傾向を示し, 生活満足度と同様, ライフスタイ ル良好者が人生満足度も高い。ソーシャルサポートは, 男性，農業者，高年層が悪く，加齢とともに社会への 貢献意識も低下している。ライフスタイル良好者が ソーシャルサポートも良好であった。

小・中学生の健康行動は, 小学生が高く中学生で低 下し，健康習慣では，運動が良好ではあるが，歯磨き， 朝の排便，偏食，睡眠は悪く，生活リズムの乱れと対 応していた。生活の満足度は, 家庭, 学校ともに中学 になると低下し，ライフスタイルが良い生徒ほど，家 庭や学校への満足度も高い。また，世代別性別に食生 活スタイルを分析すると, 中年層の食生活スタイルは, 塩分, 糖分, 油脂などについて, 若年層よりも意識が 高いが，家族団らんや领酒に問題がある。健診結果で は, 血圧, 血清総コレステロール, 肝機能障害, 肥満, 特に高年層女性の高脂血症, 男性の肝機能障害が指摘 された。子ぞもでは，小学生男子，小・中学生女子の 血清総コレステロール高値, 中学生の中性脂肪高値が
指摘された。未受診者のライフスタイルは問題が多く, 受診行動と健康的ライフスタイルとは関連して打り, 高血圧症, 高脂血症, 肝機能障害, 肥満者の健康行動 は疾患群の方が高い実践度を示した。

\section{D. 考察}

\section{1.ライフスタイル調査に関する諸問題}

第 1 年度の本研究に対して厚生省研究評価委員会の 評価として，1. 判定基準, 判定結果表をライフスタ イル調查表に添付すること，2．次年度以降の具体的 研究成果を期待する， 3 . 農村特有の問題とその対策 上の特性を明らかにすること，4 . システム工学と信 頼性工学の医学に打ける展開が期待され，この研究に 扣いて，人間性と自由を尊重し，から最大の健康増進 の方策が樹立されることを希望する，5．セルフケア， ヘルスプロモーション・プログラムの具体案とその技 法の開発を期待する，とのコメントがなされた。

これを受けて，班会議では次のような調査表の補強 が行われた。

1) 回答漏れを防ぐために，番号や記号に○をつける 方式から回答ボックスの中に丸や番号, 記号を記入す る方式に改める。

2 ）判定基準, 判定結果表, 個人への報告表を添付す る。

3 ）小学生之高齢者では，否定文の質問（健康習慣, LSI-Z)は, 有効回答率が低下するため, 表現を改める。 自記式と聞き取り法のバイアスの検討も必要である。

4）70歳以上の高齢者では,「自覚的健康度」「満足度」 などの自己判断を要する項目，食品摄取回数など平均 的頻度を回答する項目は有効回答率が低かったので検 討を要する。60歳以上の無記入率は,「自覚的健康度」 が $22 \%$,「ソーシャルサポート」が15\%であった。モラー ル・スケールは40歳代を対象にするのは若すぎて不適 当と思われる。

5 ）健康習慣項目の中で，高齢者には運動は関係ない と考光，無記入率が $11 \sim 15 \%$ と高かったので，調査主 旨説明の時に配慮が必要である。

6 ）性生活について広義の異性関係と受けとめられ ず, 性行為として理解されたため「普通」, 無記入が多 く,プライバシー侵害の抗議もあった。社会的にタブー 視されている項目への配慮が必要である。同様の問題 は,「学歴」が差別問題として誤解された。

7 ）食生活習慣では，主食の杯数が全体的に少なく, パンや麵類が換算されていないので注釈が必要であ る。

8 ）専門技術職とサービス職など職病分類の判断が困 
難であった。

以上の結果, 調査表を修正, 補強するとともに, 修 正版を第 2 年度報告書の資料として添付することとし た。また，ライフスタイルの概念の共通理解も今後重 視されよう。本共同研究班としては, ライフスタイル を単なる生活習慣, あるいは健康習慣としてのみとら えるのではなく, 生活そのものの基本構造と機能とし て体系的に理解する必要性を感じた。本研究調查を通 じて, 経済学, 社会学, 公衆衛生学などの視点を加味 し，図1に示したような整理を行った。これにより， 今後のライフスタイル調査研究が, QOL, 健康行動, 自己実現，健康的環境との相互関係などを包摂し，総 合的にアプローチ寸ることの重要性とへルスプロモー ションの重要なコア的構成要素であることを整理し た。

ライフスタイルの改善からへルスプロモーションヘ 向からプロセスについて, ライフスタイルの医学的, 社会学的, 経済学的理解と実証的解析, 学際的研究は 益々重要な領域となろう。ライフスタイルは, 最初は 「way of life」として, 個人の行動, 活動, 生産活動 として, 狭い意味でとらえられていたが, やがて「mode of life」として, 自己実現, 社会的文化的経済的満足, 健康的環境との相互関係が重視されてきた。現在では, さらに良好なエイジング, 長寿の享受, QOL, Wellness などとも包摂して, 健康の戦略として健康都市・地域 づくりの基礎とも考兄られている（Heikkinen， E.,
1989)。

ライフスタイルの改善の方法論は, 次年度の研究課 題ではあるが, 行動科学的方法, 認知科学的方法, 教 育行動工学的方法, 行動心理学, 認知科学など総合的 学際的戦略が必要とされている。例兄ばISM (Interpretive Structural Modeling) の行動, 認識, 学習構 造化法もその一例であろら（富田 拓ら，1994；守山 正樹, 1991)。健康学習について, 宮原ら, 松島らが報 告しているように self-empowerment model による 住民の主体性を重視した自律的協働的介入が重要であ り，自己制御能力の向上による行動選択としてのライ フスタイルの主体的改善が核になるものと考光られ る。

(Tones, K. et al., 1990 ; Testa, M. A. and Nackley, J. F., 1994 ; Ferrans, C, E. \& Powers, M. J., 1985)

本研究に扮いて具体的にライフスタイル改善方法の 課題として, ライフスタイルのモニタリング, 介入の 影響の評価, 行動化の促進要因分析, 改善のための健 康的環境の整備, ヘルスケアやサービスとの結合, 家 庭・職場・学校・地域の包括的アプローチ, 改善の質 の評価, ライフサイクルを通じてのスタイル改善など が明らかにされた。ヘルスプロモーションの基本的枠 組みとされる,「セルフケア」「相互援助」「健康支援環 境の創造」とも意識的に関連づける必要があろう。一 ルスプロモーションの中心は, コミュニティにあり, 生涯の生活習慣やライフスタイルと健康的環境との相

\section{【健康安全支援環境】}

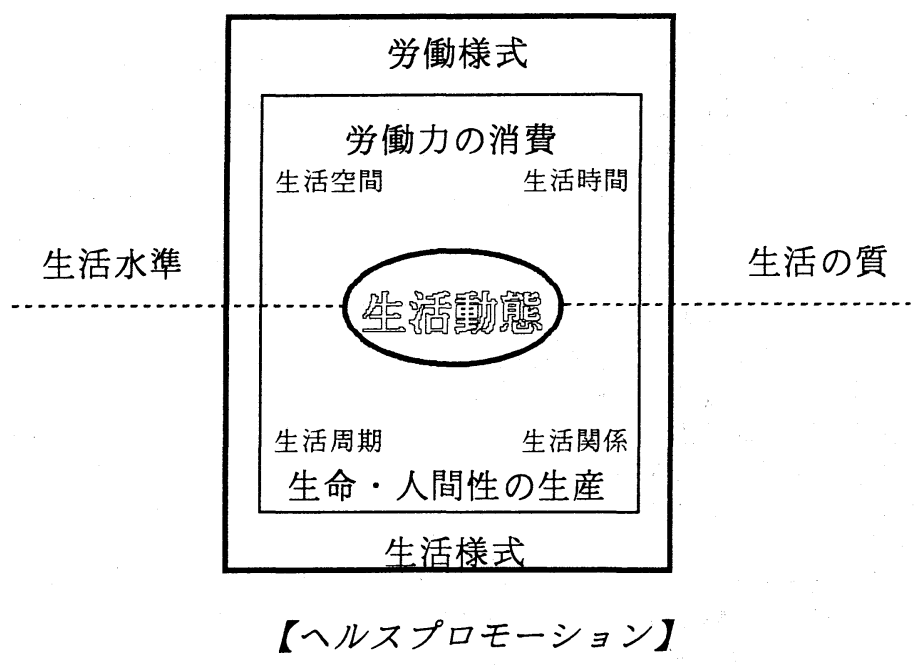

図1.ライフスタイルの構造分析図 
互作用を強めて行くことが，究極のライフスタイル改 善につながるものと考光る。例兑ば，ヘルスプロモー ションのプリシード/プロシードモデルは, 行動とラ イフスタイルの確立に関係する環境系に, 準備因子群, 強化因子群，実現因子群の介在を指摘し，これらの因 子群に対する教育・組織診断と経過評価の重要性を強 調している (Green, L. W, \& Kreuter, M, W., 1990)。

またソーシャルサポートとライフスタイルとの関 係でも, 今後, 伝統的地縁的血縁的農村コミュニティ が崩壊する中で, 農村地域のソーシャルサポートのサ イズ, 密度, 強さ, 頻度, 継続期間, 方向性, 内容, 变化, 質, 直接的効果と間接的効果 (ストレス緩衝作 用など）などを検討し，新たな農村のライフスタイル にあったネットワーク形成が重要と思われる（Mitchell, R. E. et al., 1992)。QOL との関係でみると，農 村に抢ける自己実現の基軸は何かを農村社会の扔かれ ている状況の中で明らかにし，健康で人間尊厳のライ フスタイル形成と新たな農村社会の創造を展望するこ とが，崩壊を続ける農山村の緊要な課題と思われる。

健康都市と健康農村の都邑連合形成を目指す上で, 環境生態系と快適なライフスタイルを追求する生態学 的視点, すなわち生活推移 life transition, ニッチ(生 活適所 niche, 生態学的地位), ハビタット（居住環境 habitat, 生息地) の形成を重視した社会生態学的アプ ローチも今後のライフスタイル研究に必要と考兄られ る。本研究過程で明らかになった，今後のライフスタ イル研究課題を表 1 に整理した。

\section{2.日常生活動態としてのライフスタイル}

日常の生活動態に打ける健康習慣は，コミュニティ レベルでは農山漁村の地域特性を問わず家庭生活基盤 が定着する30歳代には平均化し，同様に食生活習慣も 若干の波動を示しながら，50歳代には平準化する「収
斂的傾向」がみられる。このようなライフスタイルパ ターンの「世代的地域的収斂化」は，農村での高学歴 化によるセルフケア能力の向上，兼業化による都市型 ライフスタイルの農村への浸透, 健康情報の普及, 健 康づくり運動の進展, コミュニティ生活基盤の充実, 健康政策の発展，消費生活の向上などを背景としてい ると杉村らは推測している。今後，ライフスタイル改 善対策を立てる場合に，世代的収斂化現象を考慮する ことが効果的なへルスプロモーションにつながるもの と考觉る。

ライフステージ別の食生活あるいは健康習慣は，男 女とも30歳世代の乱れが顕著であり，ヘルシーライフ スタイルの「活断層」とも呼ぶべき世代的不安定層で ある。安定化する中年層では, 塩分, 糖分, 脂肪の摂 取などは，良く習慣化されて招り，喫煙，飲酒，運動 だけは改善されていない。この傾向は，職業，労働条 件などが関与するためか，調査対象地域で異なり，林 らは秋田の農村では40〜50歳代にライフスタイルの乱 れが顕著と報告している。一般に加齢とともに食習慣 は良く，運動は低下傾向にある。配偶者の存在，家族 構成, 経済状態もこれらに関与しているものと考光ら れる。

健康習慣は，農山村では，一般に女性の方が男性よ りも良く，女性で栄養，男性では休養への配慮が良く なされている。年齢階層別では，高年層の方が中年層 よりも良く，高齢化するほど良い傾向を示していた。 林ら，宮原らは，高齢者の慢性疾患に対する医師，保 健婦などの指導継続期間を評価している。野尻らは, 農山村のみならず，労働の厳しい漁村でも同様の傾向 が見られる事を報告した。

小山らは, 農村住民の 7 割がライフスタイルの改善 を要していること，職業別では現業，サービス業，管 理職が悪く, 特に青年層の健康自覚度の高さと行動変

表 1 .ライフスタイル分析の課題
1.コミュニティ特性と動態
2. コミュニティの健康支持環境と健康政策
3. 個人, 家庭, 学校, 職場, 地域社会の生活動態とリンヶージ
4. 生活史的動態, 生活行動, 生活推移, 生活リズム, 生活関係, 生活文化, 生活倫理
5. 生活基盤, 生活構造, 生活時間, 生活問題, 生活行動, 生活水準, 生活空間, 生活環境
6. 生活習慣と健康習慣の阻害要因と推進要因
7. 生涯生活設計とサポートネットワーク
8. 状況介入（支援・学習）プログラムと目標とのマッチング
9. 行動変容と自己決定能力向上プロセスの評価
10. 健康環境改善のための協働プロセスの評価 (Convivial Action：自律的協働的行動) 
容との分離，その結果としての中年層の精神的疲労を 指摘している。関口らは, 都市近郊農村の青年層, 中 年層のライフスタイルの乱れがひどく, 長時間労働と ストレスを背景に不十分な睡眠，休養，そして過度の 飲酒や契煙を農業荒廃に伴う集約型農業のライフスタ イルの特徵と考学ている。

健康自覚度は30歳代を中心に青年層に高く, 高齢化 とともに低下する。実際，40歳代から健康危機が目立 ちはじめ, 山根ら, 林らはこの世代へのライフスタイ ル改善介入の必要性を指摘した。健康なライフスタイ ル実践度は，50歳代以降の女性層が良好で，野尻らは 漁村の高齢者も良好であると報告し, 小山らも最近治 療歴があり，健診や人間ドックを活用している高齢者 の実践度は高く, 実際の健康度と実践度とは逆相関す ると指摘している。李た実践度は農業と他の職業間に 差はなく, サラリーマン, 若い女性, 中年男性が実践 度が低いこと, 健康意識の高いグループは健康行動も 食生活習慣も良好であると宮原らは指摘している。

生活の満足度, 生活の質 QOL についてみると, 健康 度，健康習慣が良好で，ライフスタイルも良好である 人が人生の満足度が高い。職業的には非農よりも農業 の方が高く, 青年層よりも高年層の方が高い点が農村 の特徴と思われる。健康度や職業の内容, 心理的支援 や孤独感の有無, 手段的自立, 知的能動性, 社会的役 割と貢献度が強い人活ど人生満足度は高い傾向にあ る。平均して約 6 割の人が満足度が低く, 不満な点は 経済と余暇に集中している。家庭や近隣や友人の交流 が深い人ほど満足度が高いことも興味ある点である。 農業者では女性で50歳代, 男性で60歳代の満足度が低 く, 市部の 40 歳代の中年危機に対応している。高年層 では, 心理的孤独感, 老いの認識の拒否的傾向も2ら れ, 農業経営危機, 過柾化, 農村の高齢化社会化々の 関連が推察される。

ライフスタイル実践度と病気の関係では，小山らは 健康行動特性の低い人と多血症, 貧血症の関係がみら れたと報告し, 健診受診行動, 人間ドックの積極的利 用者が健康行動実践度が高い傾向がみられたのも興味 深い。松島らは, 健診後の指導内容・方法之健康行動 特性とを検討し, 減量, 禁煙, 運動のライフスタイル 改善率は $30 \%$ で低く, 個別集団学習方式では, 食事, 労働，健診参加などで $40 \%$ 以上の改善をみたと報告し ている。林らも, 高血圧症患者のライフスタイルが领 酒と契煙を除いて良く改善されている傾向を指摘し た。外国でも心疾患へのライフスタイルが改善介入研 究でその効果が指摘されている(Ornish, D. et al., 1990 ; Grundy, S. M., 1991)。一方, 丁寧な全村健康管
理活動を長期にわたって行っている宮原らは，健診結 果への慣れの現象により, むしろライフスタイル改善 の努力が低下し, 健診結果良好群にいわゆる「ラベリ ング効果」が生ずる危険性も指摘している。

社会的支援, 社会的貢献を通じてソーシャルサポー トとの関わりをみると,ライフスタイルが良好な人は， ソーシャルサポートも良好であった事は, ライフスタ イルと地域の健康的支援環境との相互関係の大切さを 示したものと考学る。一方, 男性の高齢者注ど人生の 満足度が低下する傾向があり, 社会的孤立, 社会的貢 献度の低下，農村の崩壊など過疎と高齢化に見舞われ ている農村の現状と関係しているものと小山らは推測 し，メンタルヘルスケアの重要性を指摘している。

社会的貢献は男性の方が女性より強く意識してい る。山根らは農山村に扮いても, 女性の中年層に抢け る役割行動の変動が顕著であり, いわゆる中年の危機 「middle-age crisis」とされる生きがいや働きがいの 危機傾向を認めた。宮原らは, 地縁的連帯の強い山村 でも近隣のソーシャルサポートのある人は $50 \%$ と低 く, 農山村特有の絆が農村崩壞とともに希薄になって いることを指摘している。岸ら（1994）は, 旧産炭地 と大都市との比較で高齢者のソーシャルサポートと健 康状態について地域コミュニティの崩壊の関連を報告 している。

こども達のライフスタイルでは, 健康の自覚度は中 学生よりも小学生が良く, 健康行動特性も小学生の方 が優れていた。健康習慣では朝食, 睡眠の達成度は高 いが，排便，歯磨き，偏食など基礎的生活習慣の確立 が悪い。宮原らは, 保育園児から高齢者まで血液性状 を追跡した貴重な報告の中で，保育園児の男児 $16 \%$, 女児 $4 \%$ に高コレステロール血症を認めて抒り, 僻地 山村の子供達へ都市部々同様の小巟成人病傾向がみら れることに注意を促している。中学生では, 家庭, 学 校への満足度は低く, ストレス回避としての飲酒, 契 煙行動へつながっている点も共通して扣り興味深い。 幼稚園など小児のライフスタイルは, 発達課題と対応 して扣り，また環境要因と成人のライフスタイルを映 しているものと考吕られる。家庭と学校の生活の満足 度の低さと子ども達への生活ストレス回避としてのラ イフスタイルの乱れは今後注意すべき問題であろう。 以上の農山村に和けるライフスタイル特性とそのマ ネージメントの要約を表 2 に要約した。

\section{E. 結論}

1. ライフスタイルの経済学, 社会学, 行動科学, 文 化人類学, 公衆衛生学など諸領域の学際的研究による 
表 2. 農山村に扔けるライフスタイル特性とマネージメント

\begin{tabular}{|c|c|}
\hline $\begin{array}{l}\text { 地域特性 } \\
\text { ○農山村 } \\
\text { 都市近郊農村 } \\
\quad \text { 漁村 }\end{array}$ & 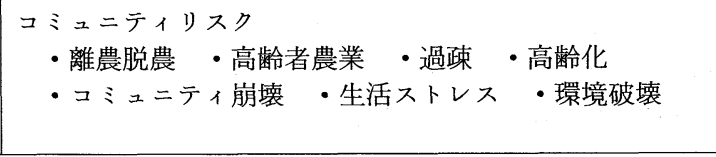 \\
\hline \multicolumn{2}{|c|}{ 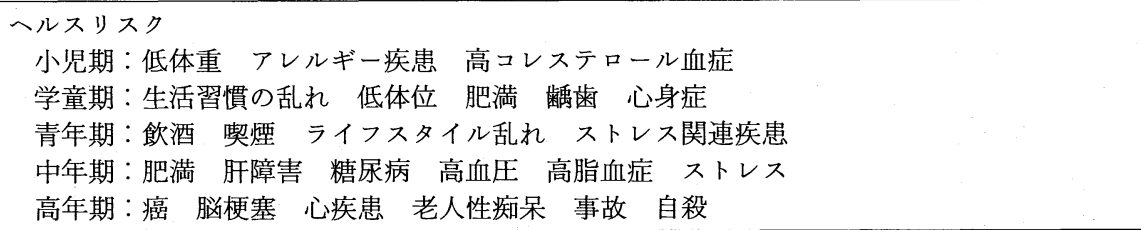 } \\
\hline 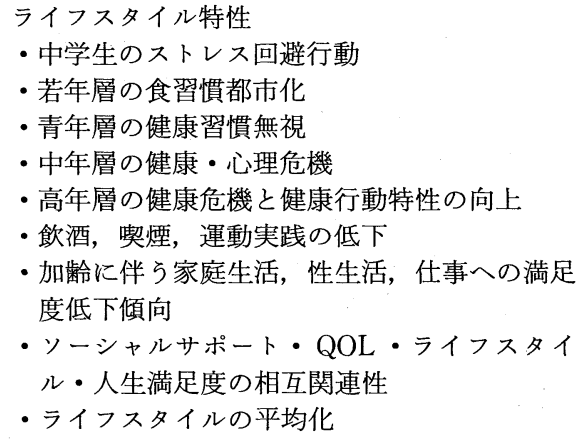 & 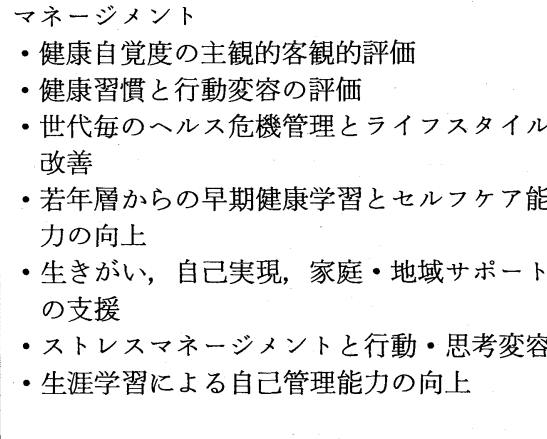 \\
\hline \multicolumn{2}{|c|}{ 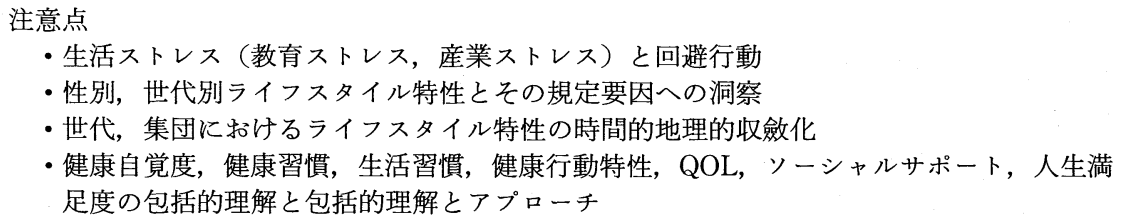 } \\
\hline
\end{tabular}

概念の体系化と調査研究方法論の開発の重要性を明ら かにした。

2. 農山村の地域特性とライフスタイルは, 都市化の 影響を受け次第に平準化しつつある。集約的農業経営 や兼業化からくる生活ストレス, 過疎化や高龄化から くるソーシャルサポートの脆弱性と不安, 農村ュミュ ニティの崩壊からくる生活の満足度の低下傾向など, ライフスタイルの課題は, 農山村, 都市近郊農村, 漁 村に共通している。

3. 農村の世代特性とライフスタイルは, 各々の世代 の生活史を反映して多様な世代特性を示すと共に，青 年・中年層ではライフスタイルの乱れと健康危機が, いわゆる「Middle-age Crisis」として顕著に現れ, や がて中年後半から高年層にむけて健康度の低下ととも にライフスタイルの平準化, 収斂化を示した。高齢化 への不安の一方, 自然と親しむ農業労働生活が高齢者 層の農業者に高い生活満足度を示しているポジティブ な側面も指摘された。
子ぞもの世代では，小児成人病傾向とともに，食生 活スタイルを中心に都市と同様の特性を示し，教育環 境と家庭環境への満足度も中学生で顕著に低下する。 このことがストレス回避行動として非健康的行動特性 を示すことを明らかにした。

4. 性別特性とライフスタイルでは, 男性に比し女性 が安定した健康習慣の維持を示し，高齢化とともにこ の傾向は強い。健康学習の機会, 労働之余㗇時間, 積 極的社会的参加，受容的で緊密な人間関係なぞの背景 が伺われる。

5. 良いライフスタイル, 良い健康状態・健康度, 良 、健康的習慣, 健康的行動変容, 生活 - 人生への満足 度は強い関連性を示して抢り, ライフスタイル改善, 生活の質 (QOL)，コミュニティのソーシャルサポート は, 包摂してアプローチして行くことが重要と考兄ら れた。

6. 今後のライフスタイル研究課題として, ライフス タイル改善とケアマネージメント，世代別健康学習プ 
ログラムと行動変容方法の開発，ライフスタイル改善 とヘルスプロモーション戦略の検討, ライフスタイル 改善とヘルシーコミュニティ創造, 特に自然環境に恵 まれながら崩壊に向から農村の「中山間地域」の重要 性の見直しなぞが緊要な課題と考吕らる。

\section{文献}

1) 森本兼軖：ライフスタイルと健康. 医学書院, 東京, 1991

2）宮原伸二：これかりの健康づくり. 三輪書店, 東京, 1994

3 ) Shea, S: Community health, community risk, community action. Am. J. Public Health, 82, 785-787, 1992

4) Ferrans, C. E. and Powers, M. Y.: Quality of life index ; Development and psychometric properties. Adv. Nurs. Sci., 8, 15-24, 1985

5 ) 岸玲子, 他: 高齢者のソーシャルサポート及びネットワー クの現状と健康状態一旧産炭地・夕張と大都市・札幌の実態 一. 日本公衛誌, 41, 474-488, 1994

6 ) Kichbusch, J. : Issues in health promotion-A charter for a new public health. Health Promotion, 1, 437-442, 1987

7 ) Mitchell, R. E. et al. : Social support and well-being ; Implications for prevention program. J. Prim. Prevent., 3, 77-98, 1992

8 ）富田 拓, 細谷憲政：健康づくりの視点からみた生活習慣. 公衆衛生. 58, 835-839, 1994

9 ) 守山正樹：保健行動の ISM 構造化一よりよい健康状態への 自発的な行動変容は可能か? 医学のあゆみ, 157, 184, 1991

10) Green, L. W. and Kreuter, M. W. : Health promotion as a public health strategy of the 1990s. Annu. Rev. Publ. H1th., 11, 319-334, 1990

11) Ornish, D. et al. : Can lifestyle changes reverse coronary heart disease? The life style heart trial. Lancet, 336, 129 $-133,1990$

12) Waters, W. E., Heikkinen, E., Dontas, A. S.: Healthy lifestyles and services for the elderly. WHO, Copenhagen, 1989

13) Grundy, S. M. : Plasma lipid lowering in short-term lifestyle change. Arch. Intern. Med., 151, 1275-1276, 1991

14) Testa, M. A. and Nackley, J. F. : Methods for quality-oflife studies. Ann. Rev. Public Health, 15, 535-591, 1994

15) Tones, K. et al.: Health education; Effectiveness and

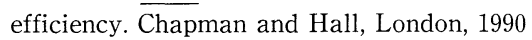

\section{F. 研 究 発 表}

1) 山根洋右, 他：島根県に括ける高齢者ヘルスケアの課題. 島 根医学, 14, 186-201, 1994

2 ) 山根洋右 : 21 世紀の健康医学への提言. 日本健康医学会雑 誌, $3,7-9,1994$

3 ) 杉村 厳: 鷹栖町高齢者モラール・スケールについて. 日農 医誌，43(2)，65-71，1994

4 ）萩原 忠, 他：農村地域に打ける健康管理の方法とその効果 の検討, 一勤務者の健康意識調査一. 日農医誌, 43, 580-581, 1994

5 ) 林 雅人: 日本人の食生活と循環器疾患. 日本内科学会東北
地方会 教育講演, 1995

6) 桂 敏樹, 他：コホート内症例対照研究における循環器疾患 のリスク要因の解析一検診所見およびその進行と死亡との 関連一. 日公衛誌, 41，208-218，1994

7 ）桂 敏樹, 他：女子学生の精神的健康度を規定する要因に関 する縦断的研究. 千大看紀要, $16,1-8,1994$

8 ）桂 敏樹, 他：地域住民の生活の質に関する研究一生活価值 観の充足からみた主観的生活満足度を規定する生活領域. 千 大看紀要, $16,9-15,1994$

9 ）佐藤有紀子, 他 : 在宅障害老人の生活行動範囲と住環境につ いて. 千大看紀要, 16, 43-50, 1994

10）野尻雅美, 他：地域に括ける健康づくりのための運動指導に 関する研究 (第 2 報) 一自転車エルゴメーター体験中のリス クについて一. 日公衛誌, 41(10), 317, 1994

11）中野正孝, 他：漁村住民の栄養・運動・休養に関する研究(5) 一生活改善意思についての検討一. 日公衛誌, 41(10), 335, 1994

12）中野正孝, 他：漁村住民の栄養・運動・休養に関する研究(5) 一生活改善意思に関係する要因の検討一. 日看研誌, 17(増), 198, 1994

13）桂 敏樹, 他：中高年に打ける生活出来事とストレスに関す る研究. 日看研誌, 17(増), 191, 1994

14）桂 敏樹, 他：中高年の Subjective Well-being に及ぼす Life Event の影響. 日公衛誌，41(10)，1026，1994

15）佐藤有紀子, 他：静岡県 1 漁村に打ける高齢者の健康調査 一健診受診者と末受診者の比較一. 日公衛誌, 41(10), 495, 1994

16）河村葉子, 他：健康づくりと運動負荷に関する基礎的研究 (第 2 報) 一女子学生の最大酸素摂取量と運動習慣との関係 一. 日公衛誌, 41(10), 314, 1994

17）白鳥潤子, 他: 精神障害者の入院と服薬に関する研究. 日公 衛誌, 41(10), 1030, 1994

18）丸岡紀子, 他：地域に扮ける健康づくりのための運動指導に 関する研究 (第 3 報) 一自転車エルゴメータ体験中の自覚症 状について一。 日公衛誌，41(10)，318，1994

19）辻 聡子, 他：地域住民の健康増進行動と環境保全に関する 研究一行動の構造および行動に関連する要因について一. 日 公衛誌，41(10)，1315，1994

20）倉田美和, 他：民間ボランティアグループ参加者のボラン ティア活動に対する意識について. 第21回関東農村医学会抄 録集, 34-35, 1994

21）中野正孝, 他：漁民住民の健康と生活に関する研究(4)一健康 づくり支援システムの検討一. 千大看紀要, 16, 107-113, 1994

22）真鍋淳子, 他 : 看護学生の看護婦イメージの研究一大学生と 短大生の比較一. 看護教育, 35, 427-433, 1994

23）中野正孝：看護研究サクセスレッスン一研究方法 4 統計 的な見方. ナース専科, $14,30-32,1994$

24）中沢あけみ, 他：農村に打けるライフスタイルの分析とへル スプロモーション技法の開発に関する研究一長野県臼田町 颃ける分析から一. 日農医誌. 43，576-577，1994

25）宮原伸二：これからの健康づくり. 三輪書店, 東京, 1994

26）宮原伸二：21世紀の健康医学への提言一人間尊厳の町づく りの立場から一. 日本健康医学会雑誌, 3，19-22, 1994

27）宮原伸二：保健センターの役割を拡大する健康づくり.ケ ア, 5, 20-23, 1994

28）中平貞行：「住民から得た情報を住民に返す」活動の展開. 
生活教育， 6，31-36，1995

29）塩飽邦憲：21世紀の健康医学への提言一環境医学の立場か ら一。 日本健康医学会雑誌, 3，14-17, 1994

30）塩飽邦憲, 他：プライマリヘルスケア教育への生命倫理教育 プログラムの導入. 山陰医学看護学教育研究会誌, 3 , $55-60,1994$

31）斉藤茂子，他：21世紀に向けた地域看護卒前教育カリキュラ ム・デザインの開発. 山陰医学看護学教育研究会誌, 3 , 43-49, 1994

32）福島哲二, 他：中小事業所に拈けるへルス・プロモーション 支援システムの形成(2) 労働災害の予防ネットワーク. 産業 医学, 36, S99, 1994

33）塩飽邦憲，他：中小事業所におけるへルス・プロモーション 支援システムの形成(4) 健康管理からのアプローチ. 産業医 学, 36, S101, 1994

34）山根洋右, 他：中小事業所に括けるへルス・プロモーション
支援システムの形成(6) コミュニティ・ヘルスケアからのア プローチ. 産業医学, 36, S103, 1994

35）塩飽邦憲，他：高齢者ヶアへのケース・マネージメントの導 入. 日公衛誌，41(10)，919，1994

36）北條宣政，他：虚血性心疾患患者における冠動脈造影所見と 血清脂肪酸構成の関連について. 日公衛誌，41(10)，603，1994

37）山根俊夫, 他：農山村における高齢者のへルスプロモーショ ンに関する研究. 日公衛誌，41(10)，909，1994

38）山根洋右：農山村地域開発事業に伴う農業従事者の健康管 理に関する研究. 日農医誌. 43，164-171，1994

39）塩飽邦憲, 他：農村コミュニティのライフスタイルとへルス プロモーションの課題. 日農医誌. 43，578一 $579 ， 1994$

40）塩飽邦憲, 他：中小事業所に打けるへルス・プロモーション 支援システムの形成. 第 4 回産業医・産業看護全国協議会抄 録集, 21-23, 1994 